\title{
CHANGES MADE IN THE NEW ROMANIAN CIVIL CODE REGARDING THE REGLEMENTATION OF FAMILY RELATIONSHIPS
}

\author{
M. I. Teacă
}

\author{
Mihaela Ioana Teacă \\ Faculty of Law, the Law Department \\ University of Oradea, Oradea, Romania \\ *Correspondence: Mihaela Ioana Teacă, University of Oradea, 26 Gen. Magheru Blvd., \\ Oradea, Romania \\ E-mail: mihaela.teaca@yahoo.fr
}

\begin{abstract}
The introduction of the Romanian Civil Code in 2011 represented for the entire socioeconomic reality in Romania a major change of the landmarks the Romanian legal system was built upon, was consolidated on and developed from. Changes in family relationships were substantial, new concepts being introduced, the existing ones adapting to the new dynamics of personal lives. A series of specific notions were introduced aiming at changing certain institutions (in the field of the matrimonial regime) or several factual situations that had not previously been acknowledged legally found now legislative recognition (the engagement). It should be noted that there were considered the international conventions to which Romania is part, and the European standards in the field, as well. The labor force migration towards the foreign markets, the insecurity of work place in the European countries have 'elasticized' the traditional Romanian family, have led to a gap in the formerly constant physical connection between the family members, have made the authorities face the problems of responsibility for the children left in the country by the parents who had gone abroad. To bring up the children left by their parents has thus become a 'duty' of grandparents, aunts, uncles, and friends of the family or neighbors. If the psychical traumas of these children cannot yet be quantified, the legislative problems they raised have now started to be regulated by the authorities.
\end{abstract}

Key words: change, Civil Code, family relations, minors.

\section{Introduction}

The changes developed in the field of family relationships in the new Romanian Civil Code are various, some being substantive changes, while others are just tinting the objectives pursued by the legislator.

Family was defined over time both by lawyers and by philosophers, sociologists, psychologists, theologians, etc., each customizing it or, on the contrary, integrating it into macro concepts, according to their own notions of analysis, values, scientific instruments and the audience addressed to.

In terms of law, we shall meet several definitions of the notion of family, this being considered "the group of people between whom there are rights and obligations arising from marriage, relation (including adoption) and other links assimilated to family relationships". It was also said that"the family is a form of social relationships between people bound

\footnotetext{
${ }^{1}$ Ion Albu, Dreptul familiei (Family Law), "Editura Didactică şi pedagocică" Publishing House, Bucharest, 1975, p. 9.
} 
together by marriage or kinship. Spouses alone, without children - form a family". ${ }^{2}$ Underlying the concept of family is that of marriage. ${ }^{3}$

A first novelty brought by the Romanian Civil Code is the regulation of engagement. According to art. 266 "Engagement is a mutual promise to go through marriage".

Although traditionally there is the institution of engagement as a preamble of marriage, after WWII it wasn't regulated any longer.

In feudalism we meet the institution under the name of "promise"or"commitment"and it was a formality required. "Engagement means swearing and presenting a future promise and involved - the consent of those who were to marry and also the parental consent, and when disagreements arose between parents, father's opinion was the overriding one. Sons and daughters could resist the engagement when parents choose fiancées or fiancés that prove dishonest and unworthy by their conduct". ${ }^{4}$

In the legislative acts of the nineteenth century, we can find engagement regulations both in Caragea Law Code and in Calimach Code.

Caragea Law Code was adopted in the Romanian Country in 1817 and had as sources: the Basilica (Byzantine laws), the law of the land, several laws in the Romanian Country and, to a lesser extent, the French Civil Code of 1804.

Calimach Code was adopted in Moldova also in 1817 and had as sources: primarily the Austrian Civil Code of 1811, the law of the land and the Byzantine laws.

According to Caragea Law Code, the engagement was a"word of deciding the wedding" being of two types: perfect (valuable) and imperfect and then not followed by"any lawful duty to necessarily committing to wedding, but binding to reparation for the damages caused by its dissolution". ${ }^{6}$

Regarding the age it was established that perfect engagement could not be fulfilled before the age of 14 for boys and 12 for girls, and the imperfect one before the $7^{\text {th }}$ year.

Returning to the current regulation, it clearly stipulates that in case of breaking the engagement, "the gifts that fiancés received in consideration of the engagement, or during it, with a view to marriage, are subject to refund, excluding normal gifts" (art. 269 Civil Code). It is not specified in the code if this refers to gifts received by any of the two from other people, or gifts that they give to each other; in the silence of the law, it is assumed that any such gifts are subject to reimbursement. However, the process of law will have to establish the criteria under which it will be appreciated, in a unified way, which of these gifts can be considered "normal" as thus excluded from the obligation of restitution by virtue of the law.

In terms of marriage there can be seen an approach to apply the contractualist theory of marriage, introducing the possibility of concluding a matrimonial convention, in which the future spouses - or the husband and wife, if it is concluded after marriage - may choose matrimonial regime that shall govern their marriage and may introduce a preciput clause, not being any longer forced, through marriage, to comply with mandatory and unique legal rules that would dictate all aspects of their family life.

\footnotetext{
${ }^{2}$ Ion P. Filipescu, Andrei I. Filipescu, Tratat de Dreptul Familiei (Study on Family Law), All Back Publishing House, Bucharest, 2001, p. 1.

${ }^{3}$ T. Ionascu, I. Christian, M. Eliescu, V. Economu, Y. Eminescu, M. I. Eremia, V. Georgescu, I. Rucareanu, Căsătoria în dreptul R.P.R.(Marriage in Romanian Law), "Editura Academiei" Publishing House, Bucharest, 1964, p.9-Intrucat casatoria sta la baza familiei, ocrotirea ei este prima conditie a ocrotirtii familiei, in intregul ei.(As marriage underlies the institution of family, its protection is the primary condition for protection of family as a whole).

${ }^{4}$ D. Firoiu, Istoria statului si dreptului românesc (History of the Romanian state and law), "Editura Fundatiei Chemarea" Publishing House, Iasi, 1992, p. 121.

${ }^{5}$ Legiuirea Caragea (Caragea Law Code), III, 14 \# 1.

${ }^{6}$ D. Firoiu, work cited p. 168.
} 
The doctrine of "freedom of contract" has been defined as"the possibility that individuals and companies have, by law, to create contracts and determine their content, reflecting the role of the will in the contracts". ${ }^{7}$

Seen in its "plenitude", the freedom of contract "consists in the legal possibility to conclude contracts, to establish their content and effects, to modify and terminate them". ${ }^{8}$ This contractual freedom has limits, regardless of the matrimonial regime the two spouses have chosen:

- the regime of legal community;

- the regime of conventional community;

- the regime of separation of patrimonies.

The limits actually represent a set of basic rules that apply to all marriages. In the legislations "with pluralist matrimonial regimes, these rules of a mandatory nature were set up into a basic matrimonial status", called by some authors "primary imperative regime". ${ }^{9}$

The primary imperative regime provides the regulatory framework both for periods of family harmony, and for those of crisis in the couple.

The rules of the primary regime refer to: payment of household expenses, fulfillment of mutual material support between spouses, distribution of spouses' rights in administration and management of their property and common heritage, protection of conjugal home, but can also refer to the income from a profession, the possible mandate between spouses, business management, termination and liquidation of the matrimonial regime, general rules on matrimonial conventions: conditions of validity, termination, modification, disclosure, enforceability of matrimonial agreements, preciput clause or prohibitions on censorship:

- correspondence

- social relations

- partner's choice of profession

The legal community regime has been known and used exclusively under the old legal regulation.

The conventional community regime, regulated by art. 366-368 Civil Code, applies when, under the conditions and limitations of law, there are derogations, under matrimonial convention, from the provisions concerning legal community regime. Unless otherwise stipulated by the matrimonial convention otherwise, the legal regime of conventional community is completed by the legal provisions concerning the legal community regime. Between the formation of the amount of own and common property characteristic to the legal community regime and that belonging to the conventional community regime, the difference lies only in the extent of the mass of goods that spouses affect to marriage through matrimonial convention.

The Civil Code provides, in terms of patrimonies separation regime, that each spouse owns exclusively property acquired before marriage and things they acquired in their own behalf thereafter.

Paragraph (2) states that "by the matrimonial convention, the parties may stipulate clauses to eliminate this regime considering the amount of goods acquired by each spouse during the marriage, which is to constitute the base for the calculation of the claims of participation. If the parties have not agreed to the contrary, the claims of participation are half of the difference in value between the two amounts of net purchases and will be due by the spouse whose net purchase amount is larger, and can be paid in cash or in nature".

\footnotetext{
${ }^{7}$ I. Albu, Liberatatea contractuală (Contractual liberty), “Dreptul” Review, no.3/1993, p. 29.

${ }^{8}$ A.A. Banciu, Raporturile patrimoniale dintre soti (Spouses' patrimonial relations), Hamangiu Publishing House, Bucharest, 2011, p. 13.

${ }^{9}$ B. Vareille, Le regime primaire, Droit patrimonial de la famille, Dalloz, Paris, 1998, p. 7.
} 
The regime of separation of patrimonies grants the holder ownership, use and management of own assets. It also includes the corresponding obligation, to contribute to the duties of marriage.

Among the advantages offered by the regime of separation of patrimonies the following can be mentioned: matrimonial independent, rapidity and efficiency of regime liquidation, protection offered to spouses if the other spouse incurs debts, amounts that have not been used for joint expenses of the marriage.

The disadvantages of this matrimonial regime are given by the mismatch between the purpose of marriage and the practicality of the material side of marriage.

The doctrine showed that the regime of separation of patrimonies "is the regime of distrust and selfishness, each spouse aiming to increase their own property without the other spouse to be able to touch it, distinguishing from the community type regime". ${ }^{10}$

Besides modifications brought by the matrimonial regime, we can also mention those that regard:

- spouses' name,

- the family home,

- the housing rights over the house rented,

- income received from the profession,

- the institution of the conventional mandate between spouses both in the legal community regime, in the conventional community regime and in the regime of separation of patrimonies,

- the spouses' right to information

- the matrimonial convention

- the preciput clause

- the right to compensation for the spouse that cannot be blamed for the divorce

- the damage reparation etc.

The higher flexibility met in the regulation of the patrimonial relations (especially) between spouse has removed the rigidity with which the system of family law code used to operate, an obsolete normative system regulating family relationships but that no longer met the economic, social or moral needs of nature. Thus, the Romanian legislation in the field has come to concord with the European one.

\section{Conclusions}

The new regulation brings, to the Romanian civil law regarding regulations of family relations, a very necessary adaptation to the evolution of social life, to the current conditions in which families live together, and a flexibility that can only be beneficial in the context of the contemporary Romanian and European society. The legislator does not impose rules any longer, but sets a framework, sometimes more permissive, sometimes more rigid, with respect to the fluidization of the matrimonial relations. However, abuses affecting marital stability are sanctioned and, above all, the best interest of children is set as the top value of the pyramid of values resorted to.

\section{Bibliography}

***The Civil Code 2011;

A. A. Banciu, Raporturile patrimoniale dintre soți (Spouses' patrimonial relations), Hamangiu Publishing House, Bucharest, 2011;

S. Cocos, Dreptul familiei (Family Law), $5^{\text {th }}$ edition revised and added, Pro Universitaria Publishing House, Bucharest, 2007;

\footnotetext{
${ }^{10} \mathrm{~S}$. Cocos, Dreptul familiei (Family Law), $5^{\text {th }}$ edition revised and added, Pro Universitaria Publishing House, Bucharest, 2007, p. 38.
} 
Ion P. Filipescu, Andrei I. Filipescu, Tratat de dreptul familiei (Study on Family Law), All Beck Publishing House, Bucharest, 2001;

B. Vareille, Le regime primaire, Droit patrimonial de la famille, Dalloz, Paris, 1998;

I. Albu, Liberatatea contractuală (Contractual liberty), "Dreptul" Review, no. 3/1993;

D. Firoiu, Istoria statului şi dreptului românesc (History of the Romanian state and law), "Editura Fundatiei Chemarea" Publishing House, Iasi, 1992;

Ion Albu, Dreptul familiei (Family Law), "Editura Didactică şi pedagocică" Publishing House, Bucharest, 1975;

T. Ionascu, I. Christian, M. Eliescu, V. Economu, Y. Eminescu, M. I. Eremia, V. Georgescu, I. Rucareanu, Casatoria în dreptul R.P.R.(Marriage in the Romanian Popular Republic's Law), "Editura Academiei” Publishing House, Bucharest, 1964;

*** Legiuirea Caragea (Caragea Law Code), III, 14 \# 1, 1817. 